\title{
Genetics of Obesity
}

\author{
Apurva Srivastava $^{1,2} \cdot$ Neena Srivastava ${ }^{2} \cdot$ Balraj Mittal $^{1}$
}

Received: 20 November 2015/ Accepted: 8 December 2015/Published online: 21 December 2015

(C) Association of Clinical Biochemists of India 2015

\begin{abstract}
Numerous classical genetic studies have proved that genes are contributory factors for obesity. Genes are directly responsible for obesity associated disorders such as Bardet-Biedl and Prader-Willi syndromes. However, both genes as well as environment are associated with obesity in the general population. Genetic epidemiological approaches, particularly genome-wide association studies, have unraveled many genes which play important roles in human obesity. Elucidation of their biological functions can be very useful for understanding pathobiology of obesity. In the near future, further exploration of obesity genetics may help to develop useful diagnostic and predictive tests for obesity treatment.
\end{abstract}

Keywords Obesity - Genetics - Epidemiology · GWAS . BMI

\section{Introduction}

Obesity is a condition that affects human health adversely. Obesity has become a serious health problem worldwide and is associated with risk of type 2 diabetes, hypertension, cardiovascular disease, stroke, and physical disabilities [1]. In fact, obesity is a complex disorder that is determined by

Balraj Mittal

bml_pgi@yahoo.com

1 Department of Medical Genetics, Sanjay Gandhi Post Graduate Institute of Medical Sciences, Rae Bareli Road, Lucknow, Uttar Pradesh 226014, India

2 Department of Physiology, King George's Medical University, Chowk, Lucknow, Uttar Pradesh 226003, India genes, environmental factors and interaction between genes and environment.

According to World Health Organization (WHO) obesity is abnormal fat buildup that may have an adverse affect on health. Most commonly used measure for obesity is BMI defined as a person's weight in kilograms divided by the square of the person's height in meters $\left(\mathrm{kg} / \mathrm{m}^{2}\right)$. Individuals with BMI $<30$ are considered as non-obese and those with BI greater than or equal to 30 are considered as obese. Although, there is a growing debate on whether different BMI cut-off points should be adapted for different ethnic groups due to the increasing evidence that the associations between BMI, percentage of body fat and body fat distribution differ across populations [2, 3]. However, the WHO Expert Consultation recommended that the current WHO BMI cut-off point $\left(\geq 30 \mathrm{~kg} / \mathrm{m}^{2}\right)$ should be retained for the international classification for obesity [4].

In addition to BMI, waist hip ratio (WHR) is another criterion to assess obesity referred as centralized obesity. The WHO states that abdominal obesity is defined as a waist-hip ratio above 0.90 for males and above 0.85 for females [5]. The WHO states that abdominal obesity is defined as a waist-hip ratio above 0.90 for males and above 0.85 for females [5]. A high WHR is also considered as high risk for obesity related complications.

\section{Facts for Genetic Component to Obesity}

Pathogenesis of obesity involves multiple interactions among environmental and genetic factors (Fig. 1).

It is commonly believed that high calorie food intake and inactive lifestyle is main reason for the rising prevalence of obesity, however, evidences have strongly suggested role of genetic component to obesity risk $[6,7]$. 
Fig. 1 Obesity and gene environment interactions. The figure above shows the diagrammatic representation of gene and environment interactions leading to obesity

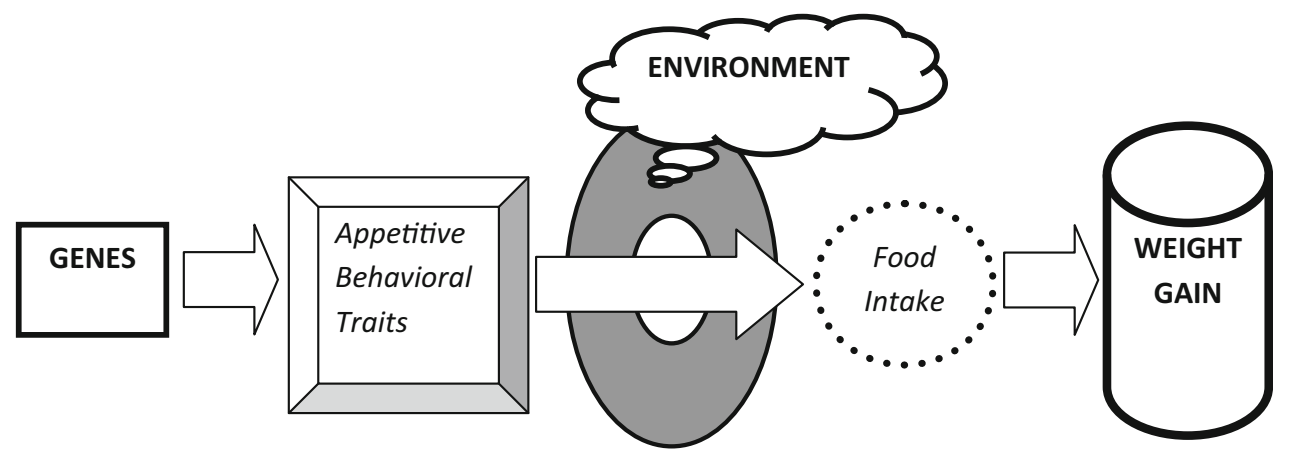

Some of supporting facts for role of genetics are mentioned below

\section{Twin Studies}

Twin studies have been used for the assessment of the genetic component to a given trait due to the fact that monozygotic (MZ) twins are genetically identical, while non identical dizygotic (DZ) twins share merely $50 \%$ of their genetic material, The concordance for fat mass among MZ twins has been reported between 70 to $90 \%$, while in DZ twins it is between 35 to $45 \%$ [8-10]. Also, it has been revealed that while there is no association between BMI of non identical twins separated at birth but there is a significant association for identical twins [11].

\section{Race or Ethnicity}

Differences in obesity prevalence based on race or ethnicity also suggests the role of genetic component to obesity risk. For example, a prevalence of $35 \%$ or less in Caucasian and Asian populations to $50 \%$ or more in Pima Indians and South Sea Island populations [12] are strong indicators for genetic component in obesity.

\section{Monogenic Forms of Obesity}

Some forms of obesity are caused by single gene mutations which are rare and severe [13]. In humans, obesity cases due to single gene mutations are reported in 11 different genes [13] including leptin, leptin receptor, proopiomelanocortin (POMC) and melanocortin four receptor (MC4R) genes. Table 1 shows the genes involved in monogenic forms of obesity.

\section{Syndromic Forms of Obesity}

Numerous Mendelian syndromes Prader-Willi [28], Alstrom syndrome [29] and Bardet-Biedl syndromes [30-32] associated wth obesity are due to distinct genetic
Table 1 Genes and monogenic forms of obesity

\begin{tabular}{lll}
\hline S. no. & Genes & References \\
\hline 1 & Leptin & {$[14-21]$} \\
2 & Leptin receptor & {$[14,22]$} \\
3 & POMC & {$[14,20,21,23]$} \\
4 & MC4R & {$[14,24-27]$} \\
\hline
\end{tabular}

defects or chromosomal abnormalities Strong candidate genes have been identified for most of the syndromes [33] and some of them also contribute significantly to human obesity. Table 2 shows the genes responsible for the syndromic forms of obesity.

\section{Genetic Association and Obesity}

Although several genes based on familial cases have been identified but majority of obese individuals occur randomly in the population. It is now accepted that obesity is a complex non-Mendelian trait that might result from numerous susceptible loci. Initially, studies that investigated for genes that predispose to obesity risk were based on candidate gene approaches.

Many candidate gene studies in relation to obesity investigated genetic variants in genes related to monogenic forms of obesity and those related to food intake and energy metabolism. However, such studies achieved incomplete success in predisposition to obesity risk because these studies are dependent on a suspected diseasecausing gene derived from a particular biological hypothesis on the pathogenesis of obesity. Moreover, the pathophysiological mechanisms underlying obesity are still unknown and constant implementation of hypothesis driven candidate gene association approach is unable to identify the genetic risk factors for the trait. Therefore, there was a great need for non hypothesis based genome wide approaches. 
Table 2 Genes and syndromic forms of obesity

\begin{tabular}{|c|c|c|c|c|}
\hline S. no & Syndrome name & Clinical heterogeneity & Loci/genes & References \\
\hline 1 & Prader-willi & $\begin{array}{l}\text { Muscular hypotony Mental retardation Hyperphagia } \\
\text { Hypogonadism Short stature }\end{array}$ & $\begin{array}{l}\text { 15q11 SRNPN Microdeletion } \\
\text { Materanal disomy }\end{array}$ & {$[34]$} \\
\hline 2 & Bardet-Biedel & $\begin{array}{l}\text { Hypogonadism Pigmentary retinopathy Polydactyly } \\
\text { Mental retardation }\end{array}$ & $\begin{array}{l}\text { BBS(1-12) Chaperonin protein MKKS } \\
\text { (Chr20) Cilliary cells proteins }\end{array}$ & $\begin{array}{c}{[30-32,} \\
35]\end{array}$ \\
\hline 3 & Alstorm & $\begin{array}{l}\text { Myocardiopathy Sensory deficit (retinopathy, deafness) } \\
\text { Dyslipidemia Diabetes }\end{array}$ & 2p14 ALSM1 & {$[29,36]$} \\
\hline 4 & $\begin{array}{l}\text { Borjson-Forssman- } \\
\text { Lehman }\end{array}$ & $\begin{array}{l}\text { Morbid obesity, epilepsy, Hypogonadism, facial } \\
\text { dismorphy }\end{array}$ & $\begin{array}{l}\text { Mutations in novel widely expressed } \\
\text { zinc-finger gene planthomeodomain } \\
\text { (PHD)-like finger (PHF6) }\end{array}$ & {$[37]$} \\
\hline 5 & $\begin{array}{l}\text { Albright's } \\
\text { hereditary } \\
\text { osteodystrophy } \\
\text { syndrome }\end{array}$ & $\begin{array}{l}\text { Obesity, short stature, round faces, ectopic Tissue } \\
\text { ossification, resistance to several hormones, Such as } \\
\text { parathyroid hormone }\end{array}$ & $\begin{array}{l}\text { Mutations in GNASI, which encodes } \\
\text { for a-subunit of the stimulatory } G \\
\text { protein (Gs a) }\end{array}$ & {$[13]$} \\
\hline 6 & Cohen syndrome & $\begin{array}{l}\text { Obesity, mental retardation, microcephaly, prominent } \\
\text { Upper central incisors and progressive retinochoroidal } \\
\text { Dystrophy }\end{array}$ & $\begin{array}{l}\text { Mutation in chromosome } 8 \mathrm{q} \text {, and a } \\
\text { novel gene, COH1 }\end{array}$ & {$[38]$} \\
\hline 7 & Fragile $\mathrm{X}$ syndrome & $\begin{array}{l}\text { Moderate to severe Mental retardation, macroorchidism, } \\
\text { large ears, macrocephaly, Prominent jaw (mandibular } \\
\text { prognathism), high-pitched Jocular speech and mild } \\
\text { obesity }\end{array}$ & $\begin{array}{l}\text { Unstable expansions of a CGG } \\
\text { trinucleotide repeat located in the } \\
\text { FMR1 (fragile X mental retardation) } \\
\text { gene }\end{array}$ & [39] \\
\hline 8 & $\begin{array}{l}\text { Wilson-Turner } \\
\text { syndrome }\end{array}$ & $\begin{array}{l}\text { Mental retardation (XLMR), obesity, gynaecomastia, } \\
\text { speech difficulties, emotional Lability, tapering fingers, } \\
\text { and small feet }\end{array}$ & $\mathrm{X}$-linked mutation & {$[40]$} \\
\hline 9 & Mehmo syndrome & $\begin{array}{l}\text { Mental retardation, epileptic seizures, hypogenitalism, } \\
\text { Microcephaly and obesity }\end{array}$ & Locus Xp21.1-p22.13 & [41] \\
\hline 10 & WAGR syndrome & $\begin{array}{l}\text { Wilms tumour, anorexia, ambiguous genitalia, mental } \\
\text { retardation }\end{array}$ & $\begin{array}{l}\text { Chromosomal deletions at } 11 \mathrm{p} 13 \text {, the } \\
\text { location of the WT1 gene }\end{array}$ & {$[42,43]$} \\
\hline 11 & $\begin{array}{l}\text { Ulnar-mammary } \\
\text { syndrome }\end{array}$ & Ulnar defects, delayed puberty and hypoplastic nipples & $\begin{array}{l}\text { Defect in the gene TBX3 located in } \\
12 q 24.1\end{array}$ & [44] \\
\hline 12 & $\begin{array}{l}\text { Simpson-Golabi- } \\
\text { Behmel, type } 2 \\
\text { (SGBS) }\end{array}$ & Visceral And skeletal abnormalities & $\begin{array}{l}\text { Alterations in the glypican-3 gene } \\
\text { (GPC3), which is located on Xq26 }\end{array}$ & {$[45]$} \\
\hline
\end{tabular}

\section{Genome-Wide Association Studies}

In context to genetic epidemiology, a genome-wide association study (GWA study, or GWAS), is evaluation of genetic variants in different individuals to spot if any genetic variant from whole genome is associated with a certain trait [46]. GWAS uses microarray technology to spot associations between specific disease or trait and genetic variants across the entire genome, rather than in a specific gene or locus (Fig. 2).

This methodology identifies genetic variants that are common in the general population and may or may not have known functional consequences. A positive association arises when there is a greater frequency of a genetic variant in individuals with a disease or trait as compared to unaffected individuals. It may be added that an association in GWAS identifies a genomic region, not a specific causative mutation involved in the development of the disease or trait. Several GWAS have revealed numerous genetic susceptibility loci for obesity risk by means of several single nucleotide polymorphisms (SNPs) constantly contributing to obesity risk [47].

GWAS are hypothesis generating and an effort to identify new loci to increase understanding of biology responsible for the susceptibility to obesity risk. GWAS have the advantage over genome-wide linkage studies that they do not require participants to be related, which allows for studies with larger sample sizes, thus increasing the power to detect true associations [48]. Since 2007, several waves of GWAS have been performed for various obesityrelated traits; each subsequent wave included larger number of sample than the preceding one.

\section{The First Wave GWAS}

The GWAS that discovered the first locus associated with BMI was part of the Welcome Trust Case Control Consortium studies [49]. In this study, genetic variation in 1924 


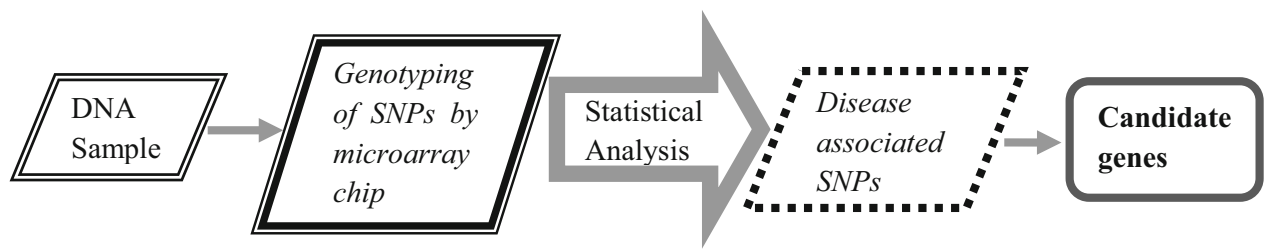

Fig. 2 Schematic representation of GWAS methodology. The figure above represents the basic methodology behind the GWAS. The DNA samples bind to a micro array chip which is a collection of millions of microscopic DNA spots attached to a solid surface. Each DNA spot contains picomoles of a specific DNA sequence, known as probes (or reporters or oligos). These can be a short section of a gene or other DNA element that are used to hybridize a cDNA sample (called

individuals with type 2 diabetes was compared with that in 2938 population-based controls. A SNP in the FTO (fat mass- and obesity-associated) gene was found to be strongly associated with type 2 diabetes, which was subsequently replicated at the second stage with 3757 cases diabetes and 5346 controls. But when analyses were adjusted for BMI, the association with type 2 diabetes was abolished indicating that the effect of FTO on type 2 diabetes was mediated through BMI.

This association with BMI was robustly replicated in a sample of 19,424 adults from seven studies and 10,172 children from two separate studies. Thus, it was concluded that FTO locus affects diabetes through its effect on obesity. Simultaneously, a GWAS in 6,142 individuals examined specifically anthropometric traits-BMI, hip circumference and weight. SNPs in two loci (FTO and PFKP) were followed up in 3,467 individuals in the GenNet family-based cohort [50]. The FTO gene as an obesity susceptibility locus has been consistently replicated in subsequent studies to be strongly associated with obesity risk.

\section{The Second Wave GWAS}

For the second round of GWAS, a meta-analysis was performed by means of data from four population-based cohorts and three disease-specific case series [51] which confirmed the robust association of FTO locus to obesity risk. At the same time, a GWAS of various obesity-related traits in 2682 Indian Asians, of which 23 genetic variants were followed up in a sample of 11,955 individuals of both Indian and European descent, identified a locus near MC4R to be associated with BMI [52].

\section{The Third Wave GWAS}

To identify more loci, the GIANT (Genetic Investigation of Anthropometric Traits) consortium was founded to bring together GWAS with anthropometric traits. The first meta- target) under high-stringency conditions. Probe-target hybridization is usually detected and quantified by detection of fluorophore-, silver-, or chemiluminescence-labeled targets to determine relative abundance of nucleic acid sequences in the target. This genotype data is statistically analyzed and is evaluated for its association with some specific disease or trait. This disease associated SNPs are then classified for their candidate gene identification

analysis by the GIANT consortium combined 15 cohorts to provide a discovery stage of 32,387 individuals. SNPs in 35 loci from discovery phase were taken forward for replication in further 14 studies of 59,082 individuals [53]. Besides confirming FTO and MC4R, loci in or near TMEM18, GNPDA2, SH2B1, MTCH2, KCTD15 and NEGR1 were also found to show genome-wide significant association with obesity risk. Concurrently, meta-analyses of GWAS for BMI and body weight were performed, combining data from five studies adding together 34,416 individuals from Iceland [47]. The 43 most significantly associated SNPs were followed up in 5586 Danes and their associations were also examined in the data available from the GWAS performed by the GIANT consortium [53].

Associations were confirmed for genetic variants at loci in or near NEGR1, TMEM18, SH2B1, KCTD15, ETV5, BDNF and SEC16B, as well as confirming the FTO and MC4R loci. Another locus, FAIM2 was very close to genome-wide significance for body weight. Both studies confirmed the loci in FTO and near MC4R and 4 newly identified loci SH2B1, KCTD15, TMEM18 and NEGR1 overlapped between the two studies. By the end of the third wave, a total of 12 loci had been found to be undoubtedly associated with obesity risk.

\section{The Fourth Wave GWAS}

In the fourth wave, the GIANT consortium expanded further to offer the large sample size required to discover variants with even smaller effect sizes or lower allele frequencies than those discovered in the third wave.

As such, the discovery stage comprised a meta-analysis of 46 studies including 123,865 individuals of white European descent. SNPs in the 42 most significantly associated genetic variants were taken forward for followup in 18 additional studies comprising 125,931 individuals [54]. All 12 previously established loci were confirmed, and 18 novel loci associated with BMI were discovered, totaling to 32 obesity associated loci. 
Table 3 Summary of the GWAS in context to obesity

\begin{tabular}{|c|c|c|c|}
\hline S. no. & Population & Gene & References \\
\hline 1 & European & FTO & [49] \\
\hline 2 & European & FTO, MC4R & {$[56]$} \\
\hline 3 & European, Indian Asian & MC4R & {$[52]$} \\
\hline 4 & European & $\begin{array}{l}\text { FTO, MC4R, TMEM18, KCTD15, GNPDA2, SH2B1, MTCH2 and } \\
\text { NEGR1 }\end{array}$ & {$[53]$} \\
\hline 5 & $\begin{array}{l}\text { Icelandic, Dutch, European Americans, } \\
\text { African American, Scandinavians, Danish }\end{array}$ & FTO, MC4R, BDNF and SH2B1 & {$[47]$} \\
\hline 6 & Northern Finland & FTO, MC4R, OLFM4 and ADCY3 & {$[57]$} \\
\hline 9 & Sardinia & FTO and PFKP & {$[50]$} \\
\hline 11 & Europeans & FTO, NPC1, MAF, PTER and MC4R & {$[58]$} \\
\hline 12 & Caucasian & NRXN3, FTO and MC4R & {$[59]$} \\
\hline 13 & European & FTO & {$[60]$} \\
\hline 14 & Hispanic & VAT, SAT, VSR, RGS6, NGEF, ASB18, VAV2 & {$[61]$} \\
\hline 15 & African Americans & TMEM212, CDH12, MFAP3, GALNT10, SLC39A11and FER1L4 & {$[62]$} \\
\hline 16 & Caucasian & FTO, SH2B1, MC4R, KCTD15 and NRXN3 & [63] \\
\hline 17 & Korean & $\begin{array}{l}\text { BDNF,MTCH2, FTO,MC4R, SEC16B, TFAP2B, TMEM18, FAIM2, } \\
\text { TNNI3 K, NUDT3, MTIF3 and MAP2K5 }\end{array}$ & {$[64]$} \\
\hline 18 & European & $\begin{array}{l}\text { FTO, TMEM18, MC4R, TNN13 K, SEC16B, GNPDA2, POMC, PRKD1, } \\
\text { CADM2, NRXN3, QPCTL, FANCL }\end{array}$ & {$[65]$} \\
\hline 20 & European & $\begin{array}{l}\text { EFEMP1, BMP6, MIR-129-2/HSD17B12, PRDM11, WWOX, KCNJ2, } \\
\text { GSTCD and PTCH1 }\end{array}$ & {$[66]$} \\
\hline 21 & European & $\begin{array}{l}\text { LINC01122, NLRC3-ADCY9, GPRC5B-GP2, BDNF, MC4R, AGBL4- } \\
\text { ELAVL4, ATP2A1-SBK1, TCF7L2, GIPR, IRS1, FOXO3, ASB4, } \\
\text { RPTOR, NPC1, CREB1, FAM57B, APOBR, HSD17B12, PTBP2, } \\
\text { ELAVL4, CELF1, RALYL, MAP2K5, MAPK3, FAIM2, PARK2 and } \\
\text { OLFM4 }\end{array}$ & {$[55]$} \\
\hline
\end{tabular}

Recently, a study of 97 loci revealed physiological mechanisms leading to obesity. The findings of the study revealed a connection between obesity and metabolic diseases suggesting that physiological and molecular pathways are contributing to obesity risk. These results also signify that obesity is a disorder with very complex biology [55]. Tables 3 and 4 summarize the GWAS identified genes and their genetic variants associated with obesity phenotype.

\section{Replication of GWAS}

Several replication studies of GWAS were performed in different populations. In the population architecture using genomics and epidemiology study thirteen SNPs in eight genes previously associated with BMI were selected for genotyping based on prior GWAS findings of positive association with BMI or obesity. This large and diverse study replicated and generalized associations between 13 SNPs and BMI. The fraction of SNPs that generalized to non-European other racial/ethnic groups varied substantially and appeared to be somewhat dependent on LD patterns [70].

A longitudinal study to examine the long-term effects of candidate SNPs previously reported as BMI risk variants in
GWAS confirmed that risk variants of genes implicated in pathways related to neural development and cell metabolism exert major longitudinal effects on BMI, Also, there are different sets of risk variants associated with childhood and adulthood BMI [71]. In a large GWAS meta-analysis, comprising over 87,000 women identified 30 novel loci for the timing of menarche, and provide evidence for a further 10 possible novel loci. These loci were in/near genes associated with cellular development, body weight regulation and hormonal regulation with a wide variety of other biological functions [72].

Similarly, several GWA meta-analyses have identified additional susceptibility loci responsible for obesity [47, 53, 54, 73-75]. A recent meta-analysis of body mass index identified 97 BMI-associated loci. Five loci demonstrated clear evidence of several independent association signals, and many loci had significant effects on other metabolic phenotypes. Pathway analyses provided strong support for a role of the central nervous system in obesity susceptibility and implicated new genes and pathways, including those related to synaptic function, glutamate signaling, insulin secretion/action, energy metabolism, lipid biology and adipogenesis [55]. Table 5 summarizes the GWAS replication studied in context to obesity phenotype. 
Table 4 Summary of GWAS identified SNPs with obesity phenotype

\begin{tabular}{|c|c|c|c|}
\hline S. no. & SNP & Gene & Study references \\
\hline 1 & rs7566605 & INSIG2 & {$[67]$} \\
\hline 2 & rs7903146 & TCF7L2 & [68] \\
\hline 3 & rs 12255372 & TCF7L2 & \\
\hline 4 & rs8050136 & FTO & \\
\hline 5 & rs7190492 & FTO & \\
\hline 6 & rs9939973 & FTO & [69] \\
\hline 7 & rs1421085 & FTO & {$[60]$} \\
\hline 8 & rs1121980 & FTO & \\
\hline 9 & rs17817449 & FTO & \\
\hline 10 & rs3751812 & FTO & \\
\hline 11 & rs9939609 & FTO & [49] \\
\hline 12 & rs17782313 & MC4R & {$[56]$} \\
\hline 13 & rs6548238 & TMEM18 & {$[53]$} \\
\hline 14 & rs11084753 & KCTD15 & \\
\hline 15 & rs10938397 & GNPDA2 & \\
\hline 16 & rs7498665 & SH2B1 & \\
\hline 17 & rs 10838738 & МТCH2 & \\
\hline 18 & rs 2815752 & NEGR1 & [57] \\
\hline 19 & rs11676272 & ADCY3 & \\
\hline 20 & rs12429545 & OLFM4 & \\
\hline 21 & rs9299 & HOXB5 & \\
\hline 22 & rs6602024 & PFKP & {$[50]$} \\
\hline 23 & rs9930506 & FTO & \\
\hline 24 & rs10146997 & NRXN3 & [59] \\
\hline 25 & rs6794092 & TMEM212 & {$[62]$} \\
\hline 26 & rs2033195 & MFAP3 & \\
\hline 27 & rs815611 & GALNT10 & \\
\hline 28 & rs 268972 & CDH12 & \\
\hline 29 & rs6088887 & FER1L4 & \\
\hline 30 & rs8077681 & SLC39A11 & \\
\hline 31 & rs11624704 & NRXN3 & [63] \\
\hline 32 & rs17817449 & FTO & \\
\hline 33 & rs9940128 & FTO & {$[65]$} \\
\hline 34 & rs12463617 & TMEM18 & \\
\hline 35 & rs7234864 & MC4R & \\
\hline 36 & rs 12142020, rs 1514175 & TNNI3 K & \\
\hline 37 & rs7234864 & MC4R/PMAIP1 & \\
\hline 38 & rs591120, rs543874 & SEC16B & \\
\hline 39 & rs13130484 & GNPDA2 & \\
\hline 40 & rs1561288 & POMC & \\
\hline 41 & rs11847697 & PRKD1 & \\
\hline 42 & rs13078807 & CADM2 & \\
\hline 43 & rs7359397 & SH2B1 & \\
\hline 44 & rs 10150332 & NRXN3 & \\
\hline 45 & rs10968576 & LRRN6NC & \\
\hline 46 & rs2287019 & QPCTL & \\
\hline 47 & rs887912 & FANCL & \\
\hline 48 & rs9299 & HOX5 & \\
\hline 49 & rs9568856 & OLFM4 & \\
\hline 50 & rs7759938, rs314268 and rs314276 & LIN28B & \\
\hline
\end{tabular}


Table 4 continued

\begin{tabular}{llll}
\hline S. no. & SNP & Gene & Study references \\
\hline 51 & rs9783304, rs2862996, rs10768966, and rs6485443 & HSD17B12 & {$[66]$} \\
52 & rs1430189 & EFEMP1 & {$[55]$} \\
53 & rs492400 & ZNF142 & \\
54 & rs492400 & TLL4 & \\
55 & rs17001654 & NUP54 & \\
56 & rs4740619, & CCDC171 & \\
57 & rs2176598 & HSD17B12 & \\
58 & rs3849570 & GBE1 & \\
59 & rs3736485 & DMXL2 & \\
60 & rs7164727 & BBS4 & \\
61 & rs9925964 & ZNF646 & \\
\hline
\end{tabular}

Table 5 Summary of the GWA replication studied in context to obesity

\begin{tabular}{|c|c|c|c|}
\hline $\begin{array}{l}\text { S. } \\
\text { no. }\end{array}$ & Population & Gene variants & References \\
\hline 1 & $\begin{array}{l}\text { Northern } \\
\text { Sweden }\end{array}$ & $\begin{array}{l}\text { FTO rs1121980, MC4R rs17782313, GNPDA2 rs10938397, SH2B1 rs7498665, MTCH2 rs4752856, } \\
\text { NEGR1 rs2815752 }\end{array}$ & {$[76,77]$} \\
\hline 2 & Danish & $\begin{array}{l}\text { TMEM18 rs2867125, GNPDA2 rs10938397, SEC16B rs543874, TFAP2B rs987237, SH2B1 rs7359397 } \\
\text { and KCTD15 rs29941 }\end{array}$ & [77] \\
\hline 3 & Caucasians & $\begin{array}{l}\text { BDNF rs6265, rs10767664 KCTD15 rs29941, TMEM18 rs2867125, MTCH2 rs10838738, FAIM2 } \\
\text { rs7138803, MAP2K5 rs2241423,TFAP2B rs } 987237 \text { and FTO rs6499640 }\end{array}$ & [71] \\
\hline 4 & $\begin{array}{l}\text { East Asian- } \\
\text { ancestry }\end{array}$ & KCNQ1 rs2237892, ALDH2/MYL2 rs671, ITIH4 rs2535633, NT5C2 rs11191580 & [78] \\
\hline 5 & European & $\begin{array}{l}\text { FTO rs1558902, TMEM } 18 \text { rs13021737, MC4R rs6567160, GNAPD2 rs10938397, SEC16 rs543874, } \\
\text { TFAP2B rs2207139, BDAF rs11030104, NEGR1 rs3101336, BCDIN3D rs7138803, ADCY3 } \\
\text { rs10182181, NRXN3 rs7141420, CADM2 rs13078960, LINGO2 rs10968576, OLFM4 rs12429545, } \\
\text { PTBP2 rs11165643, HNF4G rs17405819, LINC01122 rs1016287, RPTOR rs12940622, PRKD1 } \\
\text { rs11847697, LRP1B rs2121279, KCTD15 rs29941, NPC1rs1808579 }\end{array}$ & {$[55]$} \\
\hline
\end{tabular}

Since reproducibility is considered a key part of the scientific method in epidemiological studies, replication studies in different populations with the use of different study designs and methods therefore play an important role and help to establish that the previous studies are not an artifact [79]. Therefore the replication studies of GWAS identified loci are useful for understanding the importance and strength of their role to obesity risk.

Family studies and animal models have helped to identify many genetic actions associated with obesity. Subsequently, GWAS have determined the evolution from studying monogenic traits to ones of a more polygenic nature and have also revolutionized the field of genomics of obesity.

\section{Long-Range Interactions Between Genes Leading to Obesity}

Evidences have suggested that, obesity is influenced by genes which are being regulated by other genes. Such genes may be adjacent or located far away. A new type of long range interaction has been observed in genes related to obesity. Recently, studies have revealed that association of SNPs in FTO with obesity might be due to linkage disequilibrium between FTO intronic variations and some other genes. Ragvina et al. [80] found that the obesity-associated SNPs rs8050136, rs1421085, rs9939609, and rs17817449 in FTO regulate IRX3 gene which is located several mega base away from FTO. Smemo et al. [81] have reported that variants within FTO interact through the promoters of IRX3 gene regulating its expression and determining obesity.

Therefore, it is now evident that long range interactions between genes might play an important role for obesity risk. In our association study performed in North Indians we found that the SNPs of FTO and IRX3 were in high LD with each other. In addition we also performed higher order gene-gene interaction analysis of the FTO and IRX3 The results of these studies also supports the concept of functional connectivity of FTO and IRX3 genes and signifies long-range interactions between genes leading to obesity (Fig. 3). 


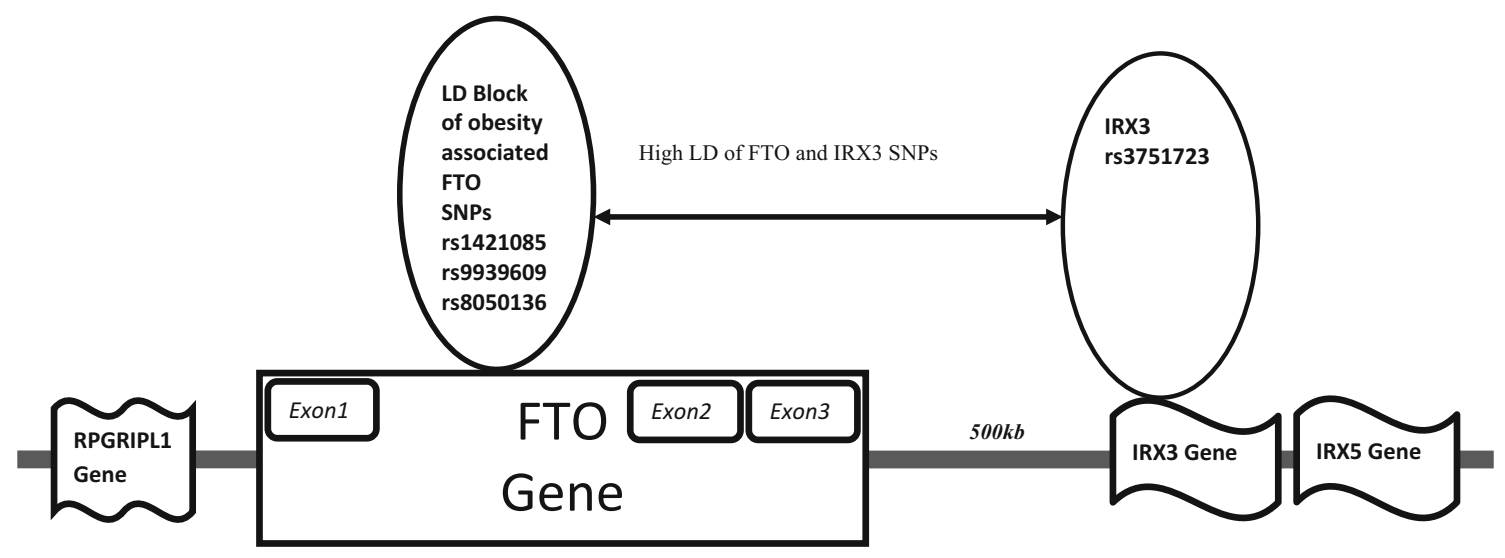

Fig. 3 Genomic organization of FTO regions in high LD to its neighboring gene IRX3. Genomic organization of FTO regions in high LD to its neighboring gene IRX3, FTO variants rs8050136,

Table 6 Summary of genetic association studies of obesity in Indian Population

\begin{tabular}{lll}
\hline $\begin{array}{l}\text { S. } \\
\text { no. }\end{array}$ & Gene & References \\
\hline 1 & CETP, APOE & {$[90]$} \\
2 & TNF- $\alpha$ & {$[91]$} \\
3 & LMNA & {$[92]$} \\
4 & MC4R & {$[86,87,89]$} \\
5 & FTO & {$[84,85,93]$} \\
6 & FTO, MC4R & {$[85]$} \\
7 & GNPDA2, TMEM18, QPCTL/GIPR, & {$[88]$} \\
& BDNF, ETV5, MAP2K5/SKOR1, & \\
& SEC16, TNKS/MSRA, MC4R, FTO & {$[94]$} \\
8 & APOB & {$[87,93]$} \\
10 & AGRP & {$[87,93]$} \\
11 & POMC & {$[95]$} \\
12 & IRX3 & {$[96]$} \\
13 & CXCR4, HHEX, TCF7L2, NGN3, FOXA2, & \\
& LOC646279, FLJ3970, TCF7L2 & \\
& and THADA & \\
\hline
\end{tabular}

\section{Indian Perspective of Obesity Genetics}

In India morbid obesity has affected $5 \%$ of the country's population. [82]. In Northern India, obesity is more prevalent in urban than rural populations [83]. In fact, obesity and related disorders have become major public health problem in India.

Numerous candidate gene studies in Indian population have conferred association of many genes to obesity risk. FTO rs9939609 variant has been shown to be associated with measures of adiposity and metabolic consequences in South Indians with an enhanced effect associated with urban living $[84,85]$.

Our candidate gene study in north India reported significant association of MC4R rs17782313 and POMC rs1421085, rs9939609, and rs17817449 are believed to act as long range enhancers for genes like IRX3 contributing to obesity phenotype

rs1042571 with morbid obesity [87]. GWAS identified obesity-associated genes such as FTO, MC4R, GNPDA2, TMEM18, QPCTL/GIPR, BDNF, ETV5, MAP2K5/ SKOR1, SEC16B and TNKS/MSRA have been shown to be associated with obesity risk in Singaporean Asian-Indian populations [88]. In addition, GWAS in Asian Indians have reported strong associations of variants near MC4R genes with insulin resistance and several obesity-related quantitative traits [89]. Table 6 summarizes genetic association studies of obesity in Indian Population.

\section{Obesity Genetics for Its Prediction And Prevention}

Traditional approaches for the management of obesity have not been so efficient and obesity surgery is an efficient but invasive method. Therefore, prevention may be considered as most promising strategy to face the obesity epidemic. So in such background, the use of genetic knowledge in clinical practice to predict individuals at high risk of obesity and obesity associated co morbidities is the only hope to prevent obesity. Promising approaches such as wholeexome and eventually whole genome sequencing, in addition to studies exploring short and long-range interactions between genes leading to obesity have the potential to guide to an exhaustive map of obesity predisposing genes in the near future. Gene identification efforts using the genetic studies have provided a more broad aspect to understand the biological mechanisms involved in the development of obesity and this information can be important not only for scientists and clinicians but for a general population too. For instance, the studies in genetics have found that people differ in their perceptions of hunger and satiety on a genetic basis and that predisposed subgroups of the population may be particularly vulnerable to obesity in "obesogenic" societies with unlimited access to food. It is clear that obesity cannot be considered as a 
consequence only of indolence or lack of will, as often thought in our societies. In the long term, progress in genetics will help to develop useful diagnostic and predictive tests and design new treatments.

Funding This study was funded by DBT, New Delhi.

\section{Compliance with Ethical Standards}

Conflict of interest The authors declare no conflicts of interest.

Ethical approval This article does not contain any studies with animals performed by any of the authors.

\section{References}

1. Haslam DW, James WP. Obesity. Lancet. 2005;366(9492): 1197-209.

2. Deurenberg-Yap M, Schmidt G, van Staveren WA, Deurenberg P. The paradox of low body mass index and high body fat percentage among Chinese, Malays and Indians in Singapore. Int J Obes Relat Metab Disord. 2000;24:1011-7.

3. Pan WH, Flegal KM, Chang HY, Yeh WT, Yeh CJ, Lee WC, Body mass index and obesity-related metabolic disorders in Taiwanese and US whites and blacks: implications for definitions of overweight and obesity for Asians. Am J Clin Nutr. 2004;79:31-9.

4. WHO expert consultation. Appropriate body-mass index for Asian populations and its implications for policy and intervention strategies. The Lancet, 2004; 157-163.

5. http://whqlibdoc.who.int/publications/2011/9789241501491_eng. pdf.

6. Friedman JM. Modern science versus the stigma of obesity. Nat Med. 2004;10:563-9.

7. Lyon HN, Hirschhorn JN. Genetics of common forms of obesity: a brief overview. Am J Clin Nutr. 2005;82:215S-7S

8. Hebebrand J, Friedel S, Schauble N, Geller F, Hinney A. Perspectives: molecular genetic research in human obesity. Obes Rev. 2003;4:139-46.

9. Farooqi IS, Rahilly S. New advances in the genetics of early onset obesity. Int J Obes. 2005;29:1149-52.

10. Bell CG, Walley AJ, Froguel P. The genetics of human obesity. Nat Rev Genet. 2005;6:221-34.

11. Stunkard AJ, Harris JR, Pedersen NL, McClearn GE. The bodymass index of twins who have been reared apart. N Engl J Med. 1990;322:1483-7.

12. Knowler WC, Pettitt DJ, Saad MF, Bennett PH. Diabetes mellitus in the Pima Indians: incidence, risk factors and pathogenesis. Diabet Metab Rev. 1990;6:1-27.

13. Farooqi IS, Rahilly S. Monogenic human obesity syndromes. Recent Prog Horm Res. 2004;59:409-24.

14. Yang W, Kelly T, He J. Genetic epidemiology of obesity. Epidemiol Rev. 2007;29:49-61.

15. Chua SC Jr, Chung WK, Wu-Peng XS, Zhang Y, Liu SM, Tartaglia $\mathrm{L}$, et al. Phenotypes of mouse diabetes and rat fatty due to mutations in the OB (leptin) receptor. Science. 1996;271:994-6.

16. Considine RV, Sinha MK, Heiman ML, Kriauciunas A, Stephens TW, Nyce MR, et al. Serum immunoreactive-leptin concentrations in normal-weight and obese humans. $\mathrm{N}$ Engl $\mathrm{J}$ Med. 1996;334:292-5.

17. Montague CT, Farooqi IS, Whitehead JP, Soos MA, Rau H, Wareham NJ, et al. Congenital leptin deficiency is associated with severe early-onset obesity in humans. Nature. 1997;387:903-8.

18. Echwald SM, Rasmussen SB, Sorensen TI, Andersen T, Tybjaerg-Hansen A, Clausen JO, et al. Identification of two novel missense mutations in the human OB gene. Int $\mathrm{J}$ Obes Relat Metab Disord. 1997;21:321-6.

19. Oksanen L, Kainulainen K, Heiman M, Mustajoki P, KauppinenMakelin R, Kontula K. Novel polymorphism of the human ob gene promoter in lean and morbidly obese subjects. Int J Obes Relat Metab Disord. 1997;21:489-94.

20. Cheung CC, Clifton DK, Steiner RA. Proopiomelanocortin neurons are direct targets for leptin in the hypothalamus. Endocrinology. 1997;138:4489-92.

21. Clement Karine, Ferre Pascal. Genetics and the pathophysiology of obesity. Pediatric Res. 2003;53:721-5.

22. Masuo K, Straznicky NE, Lambert GW, Katsuya T, Sugimoto K, Rakugi H, et al. Leptin-receptor polymorphisms relate to obesity through blunted leptin-mediated sympathetic nerve activation in a Caucasian male population. Hypertens Res. 2008;31(6): 1093-100.

23. Flickinger and Salz. The Drosophila sex determination gene snf encodes a nuclear protein with sequence and functional similarity to the mammalian U1A snRNP protein. Genes Dev. 1994;8:914-25.

24. Huszar D, Lynch CA, Fairchild-Huntress V, Dunmore JH, Fang Q, Berkemeier LR, et al. Targeted disruption of the melanocortin4 receptor results in obesity in mice. Cell. 1997;88:131-41.

25. Seeley RJ, Yagaloff KA, Fisher SL, Burn P, Thiele TE, van Dijk $\mathrm{G}$, et al. Melanocortin receptors in leptin effects. Nature. 1997;390:349.

26. Farooqi IS, Yeo GS, Keogh JM, Aminian S, Jebb SA, Butler G. Dominant and recessive inheritance of morbid obesity associated with melanocortin 4 receptor deficiency. J Clin Invest. 2000;106(2):271-9.

27. Farooqi IS, Keogh JM, Yeo GS, Lank EJ, Cheetham T, ORahilly S. Clinical spectrum of obesity and mutations in the melanocortin 4 receptor gene. N Engl J Med. 2003;348(12):1085-95.

28. Kondo I, Hamabe J, Yamamoto K, Niikawa N. Exclusion mapping of the Cohen syndrome gene from the Prader-Willi syndrome locus. Clin Genet. 1990;38:422-6.

29. Russell-Eggitt IM, Clayton PT, Coffey R, Kriss A, Taylor DS, Taylor JF. Alstrom syndrome. Report of 22 cases and literature review. Ophthalmology. 1998;105:1274-80.

30. Beales PL, Warner AM, Hitman GA, Thakker R, Flinter FA. Bardet-Biedl syndrome: a molecular and phenotypic study of 18 families. J Med Genet. 1997;34:92-8.

31. Bruford EA, Riise R, Teague PW, Porter K, Thomson KL, Moore AT, et al. Linkage mapping in 29 Bardet-Biedl syndrome families confirms loci in chromosomal regions 11q13, 15q22.3-q23, and 16q21. Genomics. 1997;41:93-9.

32. Young TL, Penney L, Woods MO, Parfrey PS, Green JS, Hefferton D, et al. A fifth locus for Bardet-Biedl syndrome maps to chromosome 2q31. Am J Hum Genet. 1999;64:900-4.

33. Rankinen $\mathrm{T}$, Zuberi A, Chagnon YC, Weisnagel SJ, Argyropoulos G, Walts B, et al. The human obesity gene Map: the 2005 update. Obesity (Silver Spring). 2006;14:529-644.

34. Goldstone AP. Prader-Willi syndrome: advances in genetics, pathophysiology and treatment. Trends Endocrinol Metab. 2004;15:12-20.

35. Chiang AP, Beck JS, Yen HJ, Tayeh MK, Scheetz TE, Swiderski RE, et al. Homozygosity mapping with SNP arrays identifies TRIM32, an E3 ubiquitin ligase, as a Bardet-Biedl syndrome gene (BBS11). Proc Natl Acad Sci USA. 2006;103:6287-92.

36. Collin GB, Marshall JD, Ikeda A, So WV, Russell-Eggitt I, Maffei $\mathrm{P}$, et al. Mutations in ALMS1 cause obesity, type 2 
diabetes and neurosensory degeneration in Alstrom syndrome. Nat Genet. 2002;31:74-8.

37. Lower KM, Turner G, Kerr BA, Mathews KD, Shaw MA, Gedeon AK, et al. Mutations in PHF6 are associated with Borjeson-Forssman-Lehmann syndrome. Nat Genet. 2002;32:661-5.

38. Chandler KE, Kidd A, Al-Gazali L, Kolehmainen J, Lehesjoki AE, Black GC, et al. Diagnostic criteria, clinical characteristics, and natural history of Cohen syndrome. J Med Genet. 2003;40:233-41.

39. Jin P, Warren ST. New insights into fragile $X$ syndrome: from molecules to neurobehaviors. Trends Biochem Sci. 2003;28: $152-8$.

40. Wilson M, Mulley J, Gedeon A, Robinson H, Turner G. New X linked syndrome of mental retardation, gynecomastia, and obesity is linked to DXS255. Am J Med Genet. 1991;40:406-13.

41. Leshinsky-Silver E, Zinger A, Bibi CN, Barash V, Sadeh M, Lev D, Sagie TL. MEHMO (mental retardation, epileptic seizures, hypogenitalism, microcephaly, obesity): a new X-linked mitochondrial disorder. Eur J Hum Genet. 2002;10:226-30.

42. Gul D, Ogur G, Tunca Y, Ozcan O. Third case of WAGR syndrome with severe obesity and constitutional deletion of chromosome [11] [p12p14]. Am J Med Genet. 2002;107:70-1.

43. Rose EA, Glaser T, Jones C, Smith CL, Lewis WH, Call KM, et al. Complete physical map of the WAGR region of $11 \mathrm{p} 13$ localizes a candidate Wilms' tumor gene. Cell. 1990;60:495-508.

44. Bamshad M, Lin RC, Law DJ, Watkins WC, Krakowiak PA, Moore ME, et al. Mutations in human TBX3 alter limb, apocrine and genital development in ulnar-mammary syndrome. Nat Genet. 2004;16:311-5.

45. Brzustowicz LM, Farrell S, Khan MB, Weksberg R. Mapping of a new SGBS locus to chromosome Xp22 in a family with a severe form of Simpson-Golabi-Behmel syndrome. Am J Hum Genet. 1999;65:779-83.

46. Manolio TA. Genome wide association studies and assessment of the risk of disease. N Engl J Med. 2010;363(2):166-76.

47. Thorleifsson G, Walters GB, Gudbjartsson DF, Steinthorsdottir V, Sulem P, Helgadottir A, et al. Genome-wide association yields new sequence variants at seven loci that associate with measures of obesity [J]. Nat Genet. 2009;41(1):18-24.

48. Hirschhorn JN, Daly MJ. Genome-wide association studies for common diseases and complex traits. Nat Rev Genet. 2005;6:95-108.

49. Frayling TM. Genome-wide association studies provide new insights into type 2 diabetes aetiology. Nat Rev Genet. 2007;8:657-62.

50. Scuteri A, Sanna S, Chen WM, Uda M, Albai G, Strait J, et al. Genome-wide association scan shows genetic variants in the FTO gene are associated with obesity-related traits. PLoS Genet. 2007;3:e115.

51. Loos RJ, Bouchard C. FTO: the first gene contributing to common forms of human obesity. Obes Rev. 2008;9:246-50.

52. Chambers JC, Elliott P, Zabaneh D, Zhang W, Li Y, Froguel P, et al. Common genetic variation near MC4R is associated with waist circumference and insulin resistance. Nat Genet. 2008:40:716-8.

53. Willer CJ, Speliotes EK, Loos RJ, Li S, Lindgren CM, Heid IM, et al. Six new loci associated with body mass index highlight a neuronal influence on body weight regulation. Nat Genet. 2009;41:25-34

54. Speliotes EK, Willer CJ, Berndt SI, Monda KL, Thorleifsson G, Jackson AU, et al. Association analyses of 249,796 individuals reveal 18 new loci associated with body mass index. Nat Genet. 2010;42:937-48.

55. Locke AE, Kahali B, Berndt SI, Justice AE, Pers TH, Day FR, et al. Genetic studies of body mass index yield new insights for obesity biology. Nature. 2015;518(7538):197-206.
56. Loos RJ, Lindgren CM, Li S, Wheeler E, Zhao JH, Prokopenko I, et al. Common variants near MC4R are associated with fat mass, weight and risk of obesity. Nat Genet. 2008;40:768-75.

57. Warrington NM, Howe LD, Paternoster L, Kaakinen M, Herrala $\mathrm{S}$, Huikari $\mathrm{V}$, et al. A genome-wide association study of body mass index across early life and childhood. Int $\mathbf{J}$ Epidemiol. 2015;44(2):700-12.

58. Meyre D, Delplanque J, Chevre JC, Lecoeur C, Lobbens S, Gallina S, Durand E, Vatin V. Genome-wide association study for early-onset and morbid adult obesity identifies three new risk loci in European populations. Nat Genet. 2009;41(2):157-9.

59. Heard-Costa NL, Zillikens MC, Monda KL, Johansson A, Harris TB, Fu M, et al. NRXN3 Is a novel locus for waist circumference: a genome-wide association study from the charge consortium. Dermitzakis ET, ed. PLoS Genet. 2009;5(6):e1000539.

60. Dina C, Meyre D, Gallina S, Durand E, Korner A, Jacobson P. Variation in FTO contributes to childhood obesity and severe adult obesity. Nat Genet. 2007;39(6):724-6.

61. Norris JM, Langefeld CD, Talbert ME, Wing MR, Haritunians T, Fingerlin TE, et al. Genome wide association study and follow-up analysis of adiposity traits in hispanic-Americans: the IRAS family study. Obesity (Silver Spring, Md). 2009;17:1932-41.

62. Ng MC, Hester JM, Wing MR, Li J, Xu J, Hicks PJ, et al. Genome-Wide Association of BMI in African Americans. Obesity (Silver Spring, Md). 2012;20(3):622-7.

63. Wang K, Li WD, Zhang CK, Wang Z, Glessner JT, Grant SF, et al. A genome-wide association study on obesity and obesityrelated traits. PLoS ONE. 2011;6(4):e18939.

64. Hong KW, Oh B. Recapitulation of genome-wide association studies on body mass index in the Korean population. Int $\mathrm{J}$ Obes (Lond). 2012;36(8):1127-30.

65. Graff M, Ngwa JS, Workalemahu T, Homuth G, Schipf S, Teumer A, et al. Genome-wide analysis of BMI in adolescents and young adults reveals additional insight into the effects of genetic loci over the life course. Hum Mol Genet. 2013;22(17):3597-607.

66. Loth DW, Artigas MS, Gharib SA, Wain LV, Franceschini N, Koch B, et al. Genome-wide association analysis identifies six new loci associated with forced vital capacity. Nat Genet. 2014;46(7):669-77.

67. Herbert A, Gerry NP, McQueen MB, Heid IM, Pfeufer A, Illig T, et al. A common genetic variant is associated with adult and childhood obesity. Science. 2006;312:279-83.

68. Grant SF, Li M, Bradfield JP, Kim CE, Annaiah K, Santa E, et al. Association analysis of the FTO gene with obesity in children of Caucasian and African ancestry reveals a common tagging SNP. PLoS ONE. 2008;3:e1746.

69. Hinney A, Nguyen TT, Scherag A, Friedel S, Bronner G, Muller TD, et al. Genome wide association (GWA) study for early onset extreme obesity supports the role of fat mass and obesity associated gene (FTO) variants. PLoS ONE. 2007;2:e1361.

70. Fesinmeyer MD, North KE, Ritchie MD, Lim U, Franceschini N, Wilkens L. Genetic risk factors for BMI and obesity in an ethnically diverse population: results from the population architecture using genomics and epidemiology (PAGE) study. Obesity. 2013;21:835-46.

71. Mei H, Chen W, Jiang F, He J, Srinivasan S, et al. Longitudinal Replication Studies of GWAS Risk SNPs Influencing Body Mass Index over the Course of Childhood and Adulthood. PLoS ONE. 2012;7(2):e31470.

72. Elks CE, Perry JR, Sulem P, Chasman DI, Franceschini N, He C, et al. Thirty new loci for age at menarche identified by a metaanalysis of genome-wide association studies. Nat Genet. 2010;42(12):1077-85.

73. Lindgren CM, Heid IM, Randall JC, Lamina C, Steinthorsdottir $\mathrm{V}$, Qi L, et al. Genome-wide association scan meta-analysis 
identifies three loci influencing adiposity and fat distribution. Allison DB, ed. PLoS Genet. 2009;5(6):e1000508.

74. Bradfield JP, Taal HR, Timpson NJ, Scherag A, Lecoeur C, Warrington NM, et al. A genome-wide association meta-analysis identifies new childhood obesity loci. Nat Genet. 2012;44: $526-31$.

75. Tan LJ, Zhu H, He H, Wu KH, Li J, Chen XD, et al. Replication of 6 obesity genes in a meta-analysis of genome-wide association studies from diverse ancestries. PLoS ONE. 2014;9(5):e96149.

76. Renstrom F, Payne F, Nordstrom A, Brito EC, Rolandsson O, Hallmans G, et al. Replication and extension of genome-wide association study results for obesity in 4923 adults from northern Sweden. Hum Mol Genet. 2009;18(8):1489-96.

77. Paternoster L, Evans DM, Nohr EA, Holst C, Gaborieau V, Brennan P, et al. Genome-wide population-based association study of extremely overweight young adults-the goya study. PLoS ONE. 2011;6(9):e24303.

78. Wen W, Zheng W, Okada Y, Takeuchi F, Tabara Y, Hwang JY, Dorajoo R. Meta-analysis of genome-wide association studies in East Asian-ancestry populations identifies four new loci for body mass index. Hum Mol Genet. 2014;23(20):5492-504.

79. Hill AB. The environment and disease: association or causation? Proc R Soc Med. 1965;58:295-300.

80. Ragvina A, Moroc E, Fredmand D, Navratilovae P, Drivenese O, Engstromd PG, et al. Long-range gene regulation links genomic type 2 diabetes and obesity risk regions to HHEX, SOX4 and IRX3. PNAS. 2010;2:775-80.

81. Smemo S, Tena JJ, Kim KH, Gamazon ER, Sakabe NJ, GomezMarin C, et al. Obesity-associated variants within FTO form long-range functional connections with IRX3. Nature. 2014; 507(7492):371-5.

82. India facing obesity epidemic: experts. The Hindu. 2007; 10-12.

83. Yadav K, Krishnan A. Changing patterns of diet, physical activity and obesity among urban, rural and slum populations in north India. Obes Rev. 2008;9(5):400-8.

84. Ramya K, Radha V, Ghosh S, Majumder PP, Mohan V. Genetic variations in the FTO gene are associated with type 2 diabetes and obesity in south Indians (CURES-79). Diabetes Technol Ther. 2011;13(1):33-42.

85. Vasan SK, Fall T, Neville MJ, Antonisamy B, Fall $\mathrm{CH}$, Geethanjali FS. Associations of variants in FTO and near MC4R with obesity traits in South Asian Indians. Obesity (Silver Spring). 2012;20(11):2268-77.

86. Dwivedi OP, Tabassum R, Chauhan G, Kaur I, Ghosh S, Marwaha RK, et al. Strong influence of variants near MC4R on adiposity in children and adults: a cross-sectional study in Indian population. J Hum Genet. 2013;58(1):27-32.

87. Srivastava A, Mittal B, Prakash J, Narain VS, Natu SM, Srivastava N. Evaluation of MC4R [rs17782313, rs17700633], AGRP [rs3412352] and POMC [rs1042571] polymorphisms with obesity in Northern India. Oman Med J. 2014;29(2):114-8.

88. Dorajoo R, Blakemore A, Sim X, Ong RT. Replication of 13 obesity loci among Singaporean Chinese, Malay and Asian-Indian populations. Int J Obes (Lond). 2012;1:159-63.

89. Been LF, Nath SK, Ralhan SK, Wander GS, Mehra NK, Singh J, et al. Replication of association between a common variant near melanocortin-4 receptor gene and obesity-related traits in Asian Sikhs. Obesity (Silver Spring). 2010;18(2):425-9.

90. Srivastava N, Achyut BR, Prakash J, Agarwal CG, Pant DC, Mittal B. Association of cholesteryl ester transfer protein (TaqIB) and apolipoprotein E (HhaI) gene variants with obesity. Mol Cell Biochem. 2008;314(1-2):171-7.

91. Vikram NK, Bhatt SP, Bhushan B, Luthra K, Misra A, Poddar $\mathrm{PK}$, et al. Associations of $-308 \mathrm{G} / \mathrm{A}$ polymorphism of tumor necrosis factor(TNF)- $\alpha$ gene and serum TNF- $\alpha$ levels with measures of obesity, intra-abdominal and subcutaneous abdominal fat, subclinical inflammation and insulin resistance in Asian Indians in North India. Dis Markers. 2011;31(1):39-46.

92. Sharma M, Misra A, Vikram N, Suryaprakash B, Chhabra S, Garg N, et al. Genotype of the LMNA 1908C > T variant is associated with generalized obesity in Asian Indians in North India. Clin Endocrinol (Oxf). 2011;75(5):642-9.

93. Srivastava A, Mittal B, Prakash J, Srivastava P, Srivastava N. Analysis of MC4R rs17782313, POMC rs1042571, APOE-Hha1 and AGRP rs3412352 genetic variants with susceptibility to obesity risk in North Indians. Ann Hum Biol. 2015;31:1-4.

94. Srivastava N, Prakash J, Srivastava A, Agarwal CG, Pant DC, Mittal B. Association of apolipoprotein B XbaI gene polymorphism and lipid profile in northern Indian obese. Indian J Human Genet. 2013;19(1):26-31.

95. Apurva Srivastava, Balraj Mittal, Jai Prakash, Pranjal Srivastava, Nimisha Srivastava \& Neena Srivastava. Association of FTO and IRX3 genetic variants to obesity risk in north India. Ann Hum Biol. 2013; Early Online: 1-6.

96. Gupta V, Vinay DG, Sovio U, Rafiq S, KranthiKumar MV, Janipalli CS. Association study of 25 type 2 diabetes related Loci with measures of obesity in Indian sib pairs. PLoS ONE. 2013;8(1):e53944. 